2007-01-01

\title{
Some Techniques to Improve Small Groundplane Printed Monopole Performance
}

\author{
Max Ammann \\ Technological University Dublin, max.ammann@tudublin.ie \\ Matthias John \\ Technological University Dublin, matthias.john@tudublin.ie
}

Follow this and additional works at: https://arrow.tudublin.ie/engschececon

Part of the Electrical and Computer Engineering Commons

\section{Recommended Citation}

Ammann, M. \& John, M. (2007) Some techniques to improve small groundplane printed monopole performance. IEEE Antennas and Propagation International Symposium, pp.2825-2828. Honolulu, 9-15 June, 2007, doi:10.1109/APS.2007.4396123

This Conference Paper is brought to you for free and open access by the School of Electrical and Electronic Engineering at ARROW@TU Dublin. It has been accepted for inclusion in Conference papers by an authorized administrator of ARROW@TU Dublin. For more information, please contact arrow.admin@tudublin.ie, aisling.coyne@tudublin.ie,gerard.connolly@tudublin.ie.

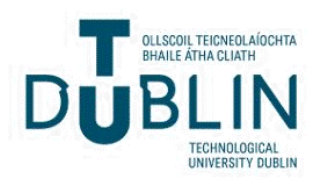




\title{
SOME TECHNIQUES \\ TO IMPROVE SMALL GROUNDPLANE PRINTED MONOPOLE PERFORMANCE
}

\author{
M. J. Ammann and M. John \\ Centre for Telecommunications Value-chain Research \\ School of Electronic \& Communications Engineering \\ Dublin Institute of Technology, \\ Kevin St., Dublin 8, Ireland.
}

\section{INTRODUCTION}

Printed planar monopole antennas are enjoying considerable popularity and publicity to their low-profile, wide bandwidth, quasi-omnidirectional radiation characteristics and their ease of integratability into devices [1-2]. It is known that classical monopole-type antenna performance is heavily dependent on groundplane effects [3-5]. Printed monopole antennas show similar dependence, but the groundplane lies in the same plane as the radiator. The impedance bandwidth and radiation properties of a strip monopole have been shown to be heavily dependent on groundplane size [5]. The groundplane (GP) is of primary importance and when miniaturised, the antenna properties change significantly. Techniques to improve the performance of printed antennas on small groundplanes are presented.

\section{GROUNDPLANE DEPENDENT EFFECTS}

A proliferation of wideband printed antenna designs employing radiator shapes including, circular disc, elliptical, polygonal and rectangular geometries have recently been reported, mainly driven by both the recent allocation of a broad spectrum for UWB applications and the increased demand for small terminal antennas, suitable for integration into portable devices. The antenna performance is heavily dependent on groundplane size. A relatively small change in GP size of about $40 \%$ can change the impedance bandwidth by a factor of 6 [5]. It has also been shown that small groundplanes can place severe restrictions on both the lower frequency of operation and the bandwidth. For illustration, a simple printed strip monopole is presented. The monopole is printed on one side of an FR4 substrate and the groundplane is located on the opposite side. The antenna is fed by a $50 \Omega$ microstrip line, of width $w=2.4 \mathrm{~mm}$. This line extends above the groundplane by a length $l=30 \mathrm{~mm}\left(0.2 \lambda_{0}\right.$ at $2 \mathrm{GHz}$ ). The square groundplane has dimensions $35 \times 35 \mathrm{~mm}$. The antenna is shown in Figure 1. The laminate properties are; $1 \mathrm{oz} / \mathrm{sq} . \mathrm{ft}$. EDC, $\tan \delta=0.02$, $\varepsilon_{r}=4.3, t=1.6 \mathrm{~mm}$. The measured bandwidth is $390 \mathrm{MHz}$ and the antenna covers a frequency range from $1.64 \mathrm{GHz}$ to $2.03 \mathrm{GHz}$ for $10 \mathrm{~dB} \mathrm{RL}$. This compares to bandwidths of $1050 \mathrm{MHz}$ and $190 \mathrm{MHz}$ for GP sizes of 50 and $80 \mathrm{~mm}$ square respectively. 


\section{TECHNIQUES TO ALLEVIATE GROUNDPLANE DEPENDENCY}

\section{GROUNDPLANE AUGMENTATION}

A simple technique to extend the groundplane and hence alter GP modes is to add strips along the groundplane side of the PCB edge. For extension strips $0.5 \mathrm{~mm}$ wide and $10 \mathrm{~mm}$ long, the lower edge frequency remains the same $(1.66 \mathrm{GHz})$ but the bandwidth increases from $390 \mathrm{MHz}$ to $890 \mathrm{MHz}$, without any increase in laminate size. This technique can also be used to reduce the bandwidth as seen in Figure 2. This figure illustrates the bandwidth dependence on strip length. The lower edge frequency is relatively stable at $1.66 \mathrm{GHz}$. Radiation pattern distortion is not significant.

Another method is to run the GP around the monopole as shown in Figure $1 \mathrm{~b}$. This type of groundplane window/slot style antenna can be used to significantly reduce the lower edge frequency. Bringing the ground around the monopole at $h_{s}=40 \mathrm{~mm}$ with a $0.5 \mathrm{~mm}$ strip gives a lower edge frequency of $1.32 \mathrm{GHz}$ and bandwidth of $380 \mathrm{MHz}$. This windowing technique [6] can serve as a useful method of miniaturisation. Radiation pattern distortion is minimal due this effect. Significantly wider bandwidths can be found by optimising the slot feed structure. Groundplane shaping is also useful for extending bandwidth and reducing pattern distortion at higher frequencies [7]. This is in contrast to radiator shaping, which has been successfully done using genetic algorithms [8].

\section{ASYMMETRY}

Where the groundplane is restricted in size, the use of asymmetry [9] can be used to significantly improve the impedance bandwidth, but at the expense of introducing some pattern distortion. In many cases, the pattern distortion is acceptable [10]. For this, a printed rectangular monopole as shown in Figure 3 is chosen to illustrate the effect. The monopole plate is rectangular, with the dimensions $w_{p}=20 \mathrm{~mm}$ and $h_{p}=30 \mathrm{~mm}$, which is fed by a microstrip feedline of width $w_{f}=2.5 \mathrm{~mm}$ via an SMA microstrip-launch connector. The optimum feedgap (optimised by classic powell [11]), between the plate and the groundplane is $h_{\text {gap }}=2 \mathrm{~mm}$. This antenna exhibits a maximum measured $10 \mathrm{~dB}$ RL bandwidth of $5.35 \mathrm{GHz}(1.57 \mathrm{GHz}$ to $6.91 \mathrm{GHz})$ when the GP is $50 \mathrm{~mm}$ square. When the GP is smaller, this value is reduced. For a $30 \times 30 \mathrm{~mm} \mathrm{GP}$, this value drops to $1.56 \mathrm{GHz}$. This can be significantly improved by using asymmetry in the feedline. A $4 \mathrm{~mm}$ offset yields a bandwidth of $3.87 \mathrm{GHz}$, an improvement of $258 \%$. This is shown in Figure 4.

\section{CONCLUSIONS}

It is shown that limitations imposed on printed monopole antennas by small groundplanes can be mitigated using various techniques. 


\section{REFERENCES}

1. Z.N. Chen, M.J. Ammann, X. Qing, X.H. Wu, T.S.P. See and A. Cai, "Planar antennas: Promising solutions for microwave UWB applications," IEEE Microwave Magazine, 2006, vol. 7(6), pp. 63-73.

2. J. Liang, C Chiau, X. Chen and C.G. Parini, "Printed circular disc monopole antenna for ultra wideband applications," Electronic Letters, 40, (20), pp.1246-1248, 2004.

3. A.T. Arkko, "Effect of Ground Plane Size on the Free-Space Performance of a Mobile Handset PIFA Antenna," IEE Intl. Conf. Antennas \& Propagat. (ICAP), (1), 316-319, 2003.

4. E. Antonino-Daviu, C.A. Suarez-Fajardo, M. Cabedo-Fabrés, M. Ferrando-Bataller, "Wideband Antenna for Mobile Terminals based on the Handset PCB Resonance," Microwave Opt. Technol. Lett, 48, (7), 1408-1409, 2006.

5. M. J. Ammann and M. John, "Optimum Design of the Printed Strip Monopole," IEEE Antennas \& Propagat. Mag,. 47, (6), 59-61, 2005.

6. C. J. Wang and D. F. Hse, "Studies of the Microstrip Monopole Antenna with Windowed Groundplane," Microwave Opt. Technol. Lett. 42, (5), 407-411, 2004.

7. M. J. Ammann and Z. N. Chen,

"An Asymmetrical Feed Arrangement for Improved Impedance Bandwidth of Planar Monopole Antennas," Microwave Opt. Technol. Lett., 40, (2), 156-158, 2004.

8. M. John and M. J. Ammann, "Wideband Printed Monopole Design Using a Genetic Algorithm,"

IEEE Antennas \& Wireless Propagat. Letters. 2007, (6),

9. S. Curto, M. John and M. J. Ammann,

"Groundplane Dependent Performance of Printed Antenna for MB-OFDM-UWB," $65^{\text {th }}$ IEEE Vehicular Technology. Conf, Dublin, 2007

10. C. Zhang and A. E. Fathy,

"Development of an ultra-wideband elliptical disc planar monopole antenna with improved omni-directional performance using a modified ground,"

IEEE Intl. Antennas \& Propagat Symp. Dig, 1689-1692, 2006,

11. M. John and M. J. Ammann,

"Optimisation of Impedance Bandwidth for the Printed Rectangular Monopole Antenna," Microwave and Optical Technology Letters, 2005, 47, (2) 153-154.

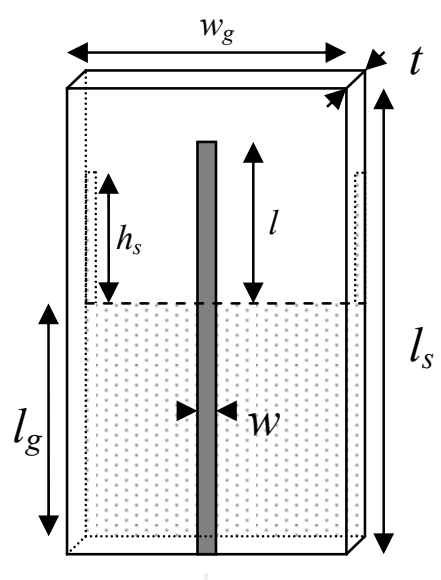

a

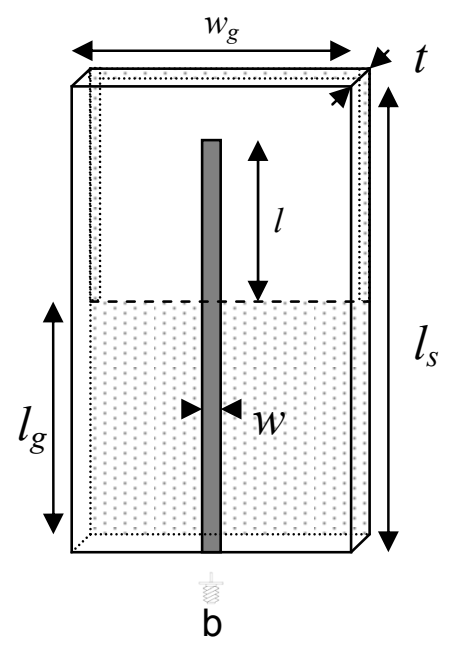

b

Figure 1. Geometry of the groundplane extension and windowed GP. 


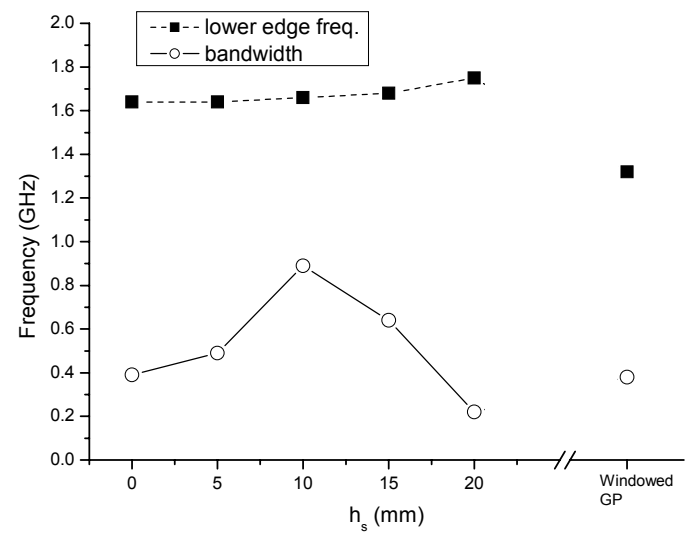

Figure 2. Bandwidth dependence on groundplane strip extension and windowed GP effect on lower edge frequency.

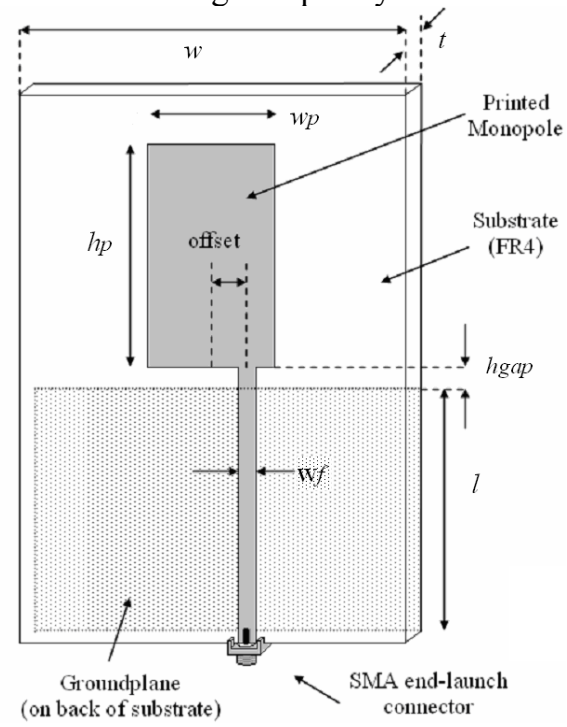

Figure 3. Geometry for the rectangular printed monopole, showing asymmetrical feed line.

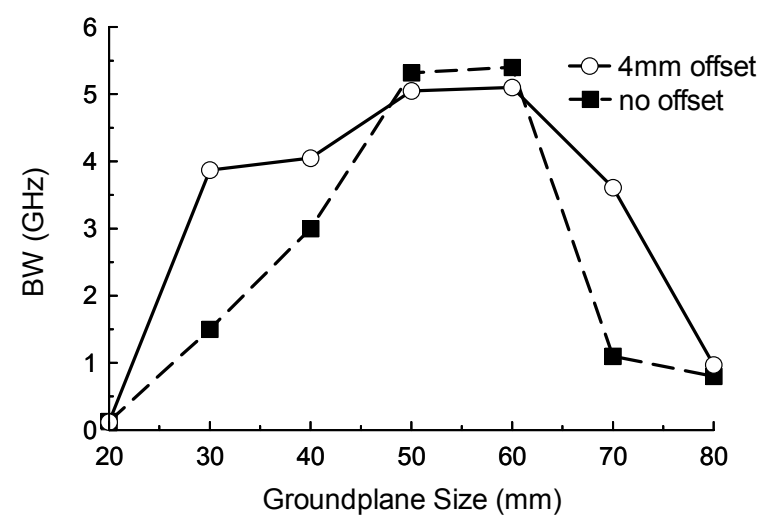

Figure 4. Measured impedance bandwidth for rectangular printed monopole against groundplane size. 